\section{Aqueous 1-Methylcyclopropene Extends Longevity and Does Not Affect Sensory Acceptability of Guatemalan-West Indian Hybrid Avocado}

\author{
Marcio Eduardo Canto Pereira ${ }^{1,5}$, Steven A. Sargent ${ }^{1}$, \\ Charles A. Sims ${ }^{2}$, Donald J. Huber ${ }^{1}$, Celso Luiz Moretti ${ }^{3}$, \\ and Jonathan $\mathrm{H}$. Crane ${ }^{4}$
}

AdDitional INDEX words. Persea americana, 1-MCP, ripening, ethylene, texture, flavor

SUMmARY. The ethylene inhibitor 1-methylcyclopropene (1-MCP) delays ripening of avocado (Persea americana) and many other fruits, but there are few reports of the influence of this ethylene inhibitor on sensory attributes. The objective of this study was to evaluate the effects of aqueous 1-MCP on fruit ripening and sensory attributes of 'Beta' avocado, a Guatemalan-West Indian hybrid. Treatment with aqueous 1-MCP at $2.77 \mu \mathrm{mol} \cdot \mathrm{L}^{-1}\left(150 \mu \mathrm{g} \cdot \mathrm{L}^{-1}\right)$ for 1 minute effectively delayed ripening by 6 days, delaying the onset of climacteric and lowering respiration rates as compared with control. Treated fruit had greener peel and firmer pulp when ripe, and untrained sensory panelists could not detect differences in texture, flavor, and overall liking between treated and untreated fruit. Immersion of 'Beta' avocado in aqueous 1 -MCP extended the shelf life to 14 days at $20{ }^{\circ} \mathrm{C}$ and $84 \%$ relative humidity, an increase of 6 days (75\%) as compared with untreated fruit, without compromising sensory acceptability. This technology has the potential to permit shipment of these fruit to more distant markets than currently possible.

A vocado is a climacteric fruit (Eaks, 1978) characterized by the accumulation of oil while attached to the plant and by various potential cancer-preventing phytochemicals (Ding et al., 2007). There are three known races of avocado: West Indian, Guatemalan, and Mexican. Cold tolerance and oil content are higher for Mexican avocados and lower for West Indian avocados, while Guatemalan fruit are intermediate. Mexican types are smaller than West Indian or Guatemalan fruit, which are usually green-skinned and large (Crane et al., 2007). Many commercial

The authors gratefully acknowledge the support of Embrapa (Brazilian Agriculture Research Corporation) for the Ph.D. scholarship to the first author, AgroFresh, Inc., in providing the l-MCP formulation for this study and to Lorenzo A. Puentes, for his dedicated work and help on the sensory analysis

${ }^{1}$ Horticultural Sciences Department, University of Florida-IFAS, P.O. Box 110690, Gainesville, FL 32611

${ }^{2}$ Food Science and Human Nutrition Department, University of Florida-IFAS, Gainesville, FL 32611

${ }^{3}$ Embrapa Hortaliças, Gama, DF, 70359-970, Brazil

${ }^{4}$ Horticultural Sciences Department, University of Florida-IFAS, Tropical Research and Education Center, Homestead, FL 33031

${ }^{5}$ Corresponding author. E-mail: marcio.pereira@ embrapa.br. cultivars are hybrids between two of these races.

Although there are many published reports for cultivars of the Mexican race, there is a lack of information on cultivars grown in the lowland tropics and subtropics that are crosses of the West Indian and Guatemalan races. These types are the main avocado cultivars produced in many tropical regions around the globe and represent significant sales for both domestic and export markets. Major producers of these tropical/ subtropical types are the Dominican Republic $(295,000$ t), Indonesia $(276,000$ t) (Food and Agriculture
Organization of the United Nations, 2013), and Brazil [160,000 t (Instituto Brasileiro de Geografia e Estatística, 2013)] in 2011. Florida accounted for $13.7 \%(28,100 \mathrm{t})$ of total U.S. production with a value of $\$ 23.5$ million during 2011-12 season (U.S. Department of Agriculture, 2013). The bulk of the avocado produced in Florida is sold outside the state, contributing significantly as a revenue generator for Florida. Florida avocados have the nutritional appeal of lower oil and lower calorie content than the 'Hass', which has been a great marketing tool for the Florida avocado industry, which is investing on fruit quality, shelf life extension and year-round availability (Crane et al., 2007). An extension of its shipping life would also represent an extension of marketing possibilities.

The hormone ethylene $\left(\mathrm{C}_{2} \mathrm{H}_{4}\right)$ is essential for avocado ripening (Zauberman et al., 1988) and controlling its action is critical to extend postharvest life. The ethylene inhibitor 1-MCP has been largely used in research to better understand ripening and senescence in many horticultural crops (Huber, 2008; Watkins, 2008 ). For avocado, gaseous 1-MCP effectively delayed ripening in concentrations ranging from 30 to 500 $\mathrm{nL} \cdot \mathrm{L}^{-1}$ following $24-\mathrm{h}$ exposure at $20{ }^{\circ} \mathrm{C}$ (Adkins et al., 2005; Feng et al., 2000; Jeong et al., 2002; Kluge et al., 2002). Treatment effects reported by these authors include reduced ethylene evolution and respiration, delayed softening and suppression of polygalacturonase activity in avocado.

Aqueous 1-MCP, originally formulated for preharvest application (Blankenship and Dole, 2003), was also found to be effective as a postharvest treatment for tomato (Solanum lycopersicum) (Choi and Huber,

\begin{tabular}{lllc}
\hline $\begin{array}{l}\text { Units } \\
\begin{array}{l}\text { To convert U.S. to SI, } \\
\text { multiply by }\end{array}\end{array}$ & U.S. unit & SI unit & $\begin{array}{l}\text { To convert SI to U.S., } \\
\text { multiply by }\end{array}$ \\
\hline 29.5735 & $\mathrm{fl} \mathrm{oz}$ & $\mathrm{mL}$ & 0.0338 \\
3.7854 & gal & $\mathrm{L}$ & 0.2642 \\
2.54 & inch(es) & $\mathrm{cm}$ & 0.3937 \\
25.4 & inch $(\mathrm{es})$ & $\mathrm{mm}$ & 0.0394 \\
0.0044 & lbf & $\mathrm{kN}$ & 224.8089 \\
4.4482 & lbf & $\mathrm{N}$ & 0.2248 \\
1000 & $\mathrm{ppb}$ & $\mathrm{ng} \cdot \mathrm{kg}^{-1}$ & 0.0010 \\
1 & $\mathrm{ppb}$ & $\mathrm{nL} \cdot \mathrm{L}^{-1}$ & 1 \\
1 & $\mathrm{ppb}$ & $\mu \mathrm{g} \cdot \mathrm{kg}^{-1}$ & 1 \\
1 & $\mathrm{ppb}$ & $\mu \mathrm{g} \cdot \mathrm{L}^{-1}$ & 1 \\
0.9072 & $\mathrm{ton}(\mathrm{s})$ & $\mathrm{t}$ & 1.1023 \\
$\left({ }^{\circ} \mathrm{F}-32\right) \div 1.8$ & ${ }^{\circ} \mathrm{F}$ & ${ }^{\circ} \mathrm{C}$ & $\left({ }^{\circ} \mathrm{C} \times 1.8\right)+32$ \\
& & &
\end{tabular}


2008), the Mexican-Guatemalan hybrid avocado 'Hass' (Choi et al., 2008), and the Guatemalan-West Indian hybrid avocado 'Booth 7' (Zhang et al., 2011). The aqueous formulation of l-MCP has the potential to be applied directly to the fruit, thus eliminating the need for lengthy exposure in sealed facilities that is required for gaseous 1-MCP treatment. Although 1-MCP has been reported to negatively affect the sensory acceptability of some fruit, notably apples [Malus sylvestris (Marin et al., 2009)] and bananas [Musa sp. (Pinheiro et al., 2010)], there have been no reports of the effect of 1-MCP on sensory quality of avocado.

The objective of this work was to evaluate ripening parameters and sensory acceptability of the GuatemalanWest Indian hybrid avocado 'Beta' treated with aqueous 1-MCP.

\section{Material and methods Plant material}

'Beta' avocado fruit were harvested early in the morning at the preclimacteric stage from an experimental planting located at the Tropical Research and Education Center (Homestead, FL) during harvesting date C (Sept. 2008). The Florida Avocado Administrative Committee establishes official harvesting dates (A to D) required for each commercial avocado cultivar grown in Florida based on minimum size and weight requirements. Harvesting date $\mathrm{C}$ refers to the third harvesting date (Florida Avocado Administrative Committee, 2008). After harvest, fruit were immediately transported to the Postharvest Horticulture Laboratory of the University of Florida, Gainesville, and stored at $20{ }^{\circ} \mathrm{C}$ overnight. The following day, sound fruit were randomized into groups for treatment application.

\subsection{Aqueous 1-MCP treatment}

Aqueous 1-MCP was prepared from formulation AFxRD-300 (2\% a.i.; AgroFresh, Philadelphia, PA) according to Choi and Huber (2008). To prepare the aqueous 1-MCP solution, AFxRD-300 powder was diluted in $30 \mathrm{~L}$ of deionized water at $20^{\circ} \mathrm{C}$. The solution was used from 10 to $45 \mathrm{~min}$ after preparation (Choi et al., 2008). Fruit were placed in mesh bags and completely immersed for $1 \mathrm{~min}$ in the aqueous $1-\mathrm{MCP}$ solution at a concentration of 2.77 $\mu \mathrm{mol} \cdot \mathrm{L}^{-1}$. Bags were gently agitated to ensure full contact of solution with fruit surface. Immediately after immersion, excess solution was drained, fruit were removed from the bags, and were dried with paper towels and stored uncovered in a single layer on trays at $20{ }^{\circ} \mathrm{C}$ and $92 \% \pm 3 \%$ relative humidity. Control fruit (immersed in water only, not exposed to 1-MCP) were stored under identical conditions. Initial quality analysis was conducted on the same day for untreated fruit.

\section{Ripening and quality parameters}

WHOLE FRUIT FIRMNESS. Whole fruit firmness was determined nondestructively during ripening, adapting the method described by Jeong et al. (2002). A nondestructive compression test was performed on whole, unpeeled fruit using a universal testing instrument (model 4411; Instron, Norwood, MA) fitted with a flat-plate probe $(5 \mathrm{~cm}$ diameter $)$ and $0.5-\mathrm{kN}$ load cell. After establishing zero force contact between the probe and the equatorial region of the fruit, the probe was driven with a crosshead speed of $0.33 \mathrm{~mm} \cdot \mathrm{s}^{-1}$. The force was recorded at $2.5-\mathrm{mm}$ deformation and was determined at two points on the equatorial region of each fruit, with a $90^{\circ}$ angle between the points. The same 10 fruit for each treatment were measured every other day and were considered at the ripe stage (limit of commercial marketability) upon reaching 10 to $15 \mathrm{~N}$ firmness.

ETHYLENE EVOLUTiON AND RESPIRATION. Ethylene evolution and respiration rates [as carbon dioxide $\left(\mathrm{CO}_{2}\right)$ evolution] were measured daily on five individual fruit per treatment. Each fruit was sealed for $20 \mathrm{~min}$ in a 2-L plastic container before sampling. A $1 \mathrm{~mL}$ gas sample was withdrawn by a plastic syringe through a rubber septum for analysis using gas chromatography as described by Jeong et al. (2002).

Weight Loss. Percent weight loss was calculated considering the fruit weight loss from the beginning of the experiment until the ripe stage. This calculation was performed for the same 10 fruit used for whole fruit firmness determination.

Peel and Pulp Color. The same fruit used for whole fruit firmness determination were also used when ripe to measure peel and pulp color (after cross sectioning the fruit) at the equatorial region (two readings per fruit) with a colorimeter (model CR400; Konica Minolta, Tokyo, Japan). The colorimeter was calibrated with a white standard tile. The results are presented as lightness $\left(\mathrm{L}^{*}\right)$, chromaticity value $\left(\mathrm{C}^{*}\right)$ and hue angle.

PulP HARDNess. This analysis was performed by using the samples from ripe mesocarp tissue to simulate the two first bites of a consumer, adapting the texture profile analysis methodology described by Yagiz et al. (2007). For each treatment, a cross-section (10 mm thick) was removed from stem end, equatorial, and blossom end of the fruit $(n=3$ fruit). From each slice, three cylindrical samples $(10 \mathrm{~mm}$ diameter $\times 10 \mathrm{~mm}$ length) were withdrawn with a cork borer from the stem-end to blossomend orientation. Each mesocarp sample was placed vertically (same sampling direction) on a flat aluminum plate and submitted to the pulp hardness test using a universal testing instrument (model 4411) fitted with a flat cylindrical probe $(13 \mathrm{~mm}$ diameter) and $0.02-\mathrm{kN}$ load cell. After establishing zero force contact between the probe and the top surface of the cylindrical sample, the probe was driven with a crosshead speed of $3.3 \mathrm{~mm} \cdot \mathrm{s}^{-1}$ to $70 \%$ of original sample height. There were two consecutive compression-decompression cycles per test. The hardness of the first and second cycles was determined using Blue Hill software (Instron).

Sensory analysis. The consumer sensory acceptance test was conducted in the sensory laboratory of the Food Science and Human Nutrition Department at the University of Florida. Fruit from each treatment were evaluated on the day the fruit reached the ripe stage. Fruit were sliced longitudinally in quarters, peeled, and the pulp was sliced into pieces of $2 \times 2 \times 1 \mathrm{~cm}$. Each panelist sat in an individual booth and received two pieces of avocado pulp served in plastic cups labeled with three digit random numbers. They were asked to evaluate texture, flavor, and overall liking using a nine-point hedonic scale where $1=$ dislike extremely, $5=$ neither like nor dislike, and $9=$ like extremely. Scores and comments were recorded directly into a computer using the software Compusense five (version 4.8.8; Compusense, Guelph, ON, Canada). 


\section{Statistical analysis}

The experiment was conducted using a completely randomized design with two treatments (untreated control and 1-MCP treated). Number of replicates varied according to analysis: 10 replicates for whole fruit firmness, weight loss, and peel and pulp color; five replicates for ethylene evolution and respiration determination; three replicates for pulp hardness; and 75 untrained panelists for sensory analysis. Data from sensory analysis were analyzed by one-way analysis of variance. Statistical procedures were performed using SAS (version 9.1.3; SAS Institute, Cary, NC). Differences between means were determined using Duncan's multiple range test.

\section{Results}

Untreated 'Beta' avocado softened rapidly from initial firmness 140 $\mathrm{N}$ to $22 \mathrm{~N}$ within $6 \mathrm{~d}$ and reached the ripe stage $(10$ to $15 \mathrm{~N})$ after $8 \mathrm{~d}$ of storage (Fig. 1). Treatment with 1MCP extended the time to ripe stage to $14 \mathrm{~d}$, representing a $75 \%$ shelf life extension.

Initial softening occurred for control and for 1-MCP-treated fruit within the first $3 \mathrm{~d}$ of storage, however, at low levels of ethylene production $\left[<0.4 \mathrm{ng} \cdot \mathrm{kg}^{-1} \cdot \mathrm{s}^{-1}\right.$ (Fig. 2A)]. From that point ethylene production in control fruit significantly increased from $0.2 \mathrm{ng} \cdot \mathrm{kg}^{-1} \cdot \mathrm{s}^{-1}$ to a peak at 78 $\mathrm{ng} \cdot \mathrm{kg}^{-1} \cdot \mathrm{s}^{-1}$ on day five, then decreased

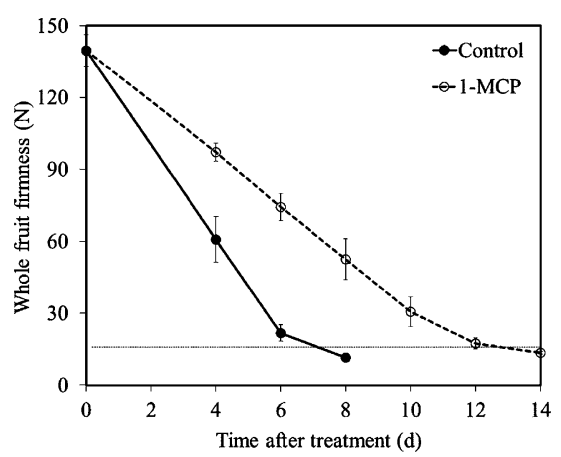

Fig. 1. Whole fruit firmness of untreated 'Beta' avocados (control) or following immersion at preclimacteric stage in aqueous 1-methylcyclopropene (1MCP) solution $2.77 \mu \mathrm{mol} \cdot \mathrm{L}^{-1}$ [150 $\left.\mu \mathrm{g} \cdot \mathrm{L}^{-1}(\mathrm{ppb})\right]$ for $1 \mathrm{~min}$ and storage at $20{ }^{\circ} \mathrm{C}\left(68.0^{\circ} \mathrm{F}\right)$. Vertical bars represent $\pm \mathrm{SE}(n=10)$. Dotted line represent firmness threshold ( $15 \mathrm{~N})$ for ripe fruit; $1 \mathrm{~N}=0.2248$ lbf. to $10 \mathrm{ng} \cdot \mathrm{kg}^{-1} \cdot \mathrm{s}^{-1}$ by the ripe stage. Fruit treated with 1-MCP exhibited increased ethylene evolution after $2 \mathrm{~d}$ of storage and peaked at $83 \mathrm{ng} \cdot \mathrm{kg}^{-1} \cdot \mathrm{s}^{-1}$ on day nine. The l-MCP treatment delayed the climacteric rise of ethylene evolution by $4 \mathrm{~d}$, but the pattern and the levels of production were very similar to untreated fruit. In addition, it is worth mentioning that firmness of both control and 1-MCP-treated fruit was similar, nearly $40 \mathrm{~N}$, at peak ethylene evolution.

Respiratory rates of untreated fruit peaked at $51 \mu \mathrm{g} \cdot \mathrm{kg}^{-1} \cdot \mathrm{s}^{-1}$ within $4 \mathrm{~d}$ of storage (Fig. 2B). For treated fruit, the increase in respiratory activity was slower than control fruit, peaking after $7 \mathrm{~d}$ at $4 \mathrm{l} \mu \mathrm{g} \cdot \mathrm{kg}^{-1} \cdot \mathrm{s}^{-1}$, $20 \%$ lower than untreated fruit.

Control fruit retained $\approx 26 \%$ more fresh weight than 1-MCP-treated fruit when ripe (Table 1 ). However, the peel color of treated fruit was greener (higher hue value) and darker (lower $\mathrm{L}^{*}$ value) than control fruit (Table $\mathrm{l}$ ); no differences were found for pulp color.

The analysis of pulp hardness of ripe fruit showed that pulp in the apical cross-section of untreated fruit was firmer than that from the equatorial and distal-end sections (Table $2)$. Treatment with 1-MCP exacerbated within fruit difference among sections, where pulp hardness at the apical end was $176 \%$ higher than that from the distal end; this difference was only $28 \%$ within untreated fruit. Pulp from all the three sections was harder in 1-MCP-treated than the corresponding section from untreated fruit.

Sensory analysis performed by 75 untrained panelists showed no significant differences between 1-MCPtreated and non-treated 'Beta' avocado for all attributes tested (Table 3).

\section{Discussion}

Avocado is a climacteric fruit that requires ethylene to ripen (Zauberman et al., 1988) and responds best to l-MCP treatment when preclimacteric (Zhang et al., 2011). This benefit of 1-MCP has been reported for gaseous treatments of avocado at 50 to $900 \mathrm{~nL} \cdot \mathrm{L}^{-1}$ for $12 \mathrm{~h}$ to $24 \mathrm{~h}$, with $50 \%$ to $75 \%$ increase in shelf life (Adkins et al., 2005; Feng et al., 2000; Jeong et al., 2002; Jeong and Huber, 2004; Kluge et al., 2002). There was a $75 \%$ extension of time to ripe stage observed in this study for aqueous 1-MCP-treated 'Beta' avocado as compared with control. This is an impressive result because the success of 1-MCP treatment depends, among other factors, on 1-MCP concentration and cultivar. Treatments with aqueous 1-MCP at 1.39 and 2.77 $\mu \mathrm{mol} \cdot \mathrm{L}^{-1}$, respectively, delayed ripening of 'Simmonds' by 33\% and 67\%, 'Booth 7' by $40 \%$ and $80 \%$, and 'Monroe' by $50 \%$ to $83 \%$ (Pereira et al., 2013). This result clearly shows the potential to use aqueous formulation of 1 -MCP, a postharvest treatment for avocado.

Despite the strong effect of l-MCP in delaying 'Beta' avocado softening, a significant part of initial softening occurred during nonevident climacteric evolution of ethylene. This may be due to either ethyleneindependent, softening-related events that occur despite the presence of an ethylene inhibitor or due to softeningrelated events that are dependent upon very low concentrations of ethylene evolution by the fruit. These mechanisms have been reported for other fruit such as apple (Tacken et al., 2010), kiwifruit [Actinidia chinensis (Mworia et al., 2011)], and melon [Cucumis melo (Nishiyama et al., 2007)]. The delay of softening caused by 1-MCP treatment was likely due to a delay in the activity of softening-related enzymes (polygalacturonase, pectin methylesterase, $\alpha$ - and $\beta$-galactosidases, and endo- $\beta$-1,4-glucanase) as previously shown for avocado (Jeong et al., 2002; Jeong and Huber, 2004).

In this study, the pattern and rates of respiration for 'Beta' avocado were more affected by aqueous 1-MCP treatment than those for ethylene evolution. Respiration rate suppression was also reported for other avocado cultivars (Choi et al., 2008; Zhang et al., 2011; Pereira et al., 2013 ) treated with aqueous 1-MCP and for other several commodities treated with gaseous 1-MCP (Watkins, 2006). Lower respiratory rates are directly related to a longer postharvest life in fresh produce. Despite the slower fruit metabolism indicated by lower respiration rates of 1-MCPtreated 'Beta' avocado, there was a complete recovery of fruit capacity to produce ethylene, as evidenced by the similar pattern and rates of ethylene evolution that occurred during storage. 


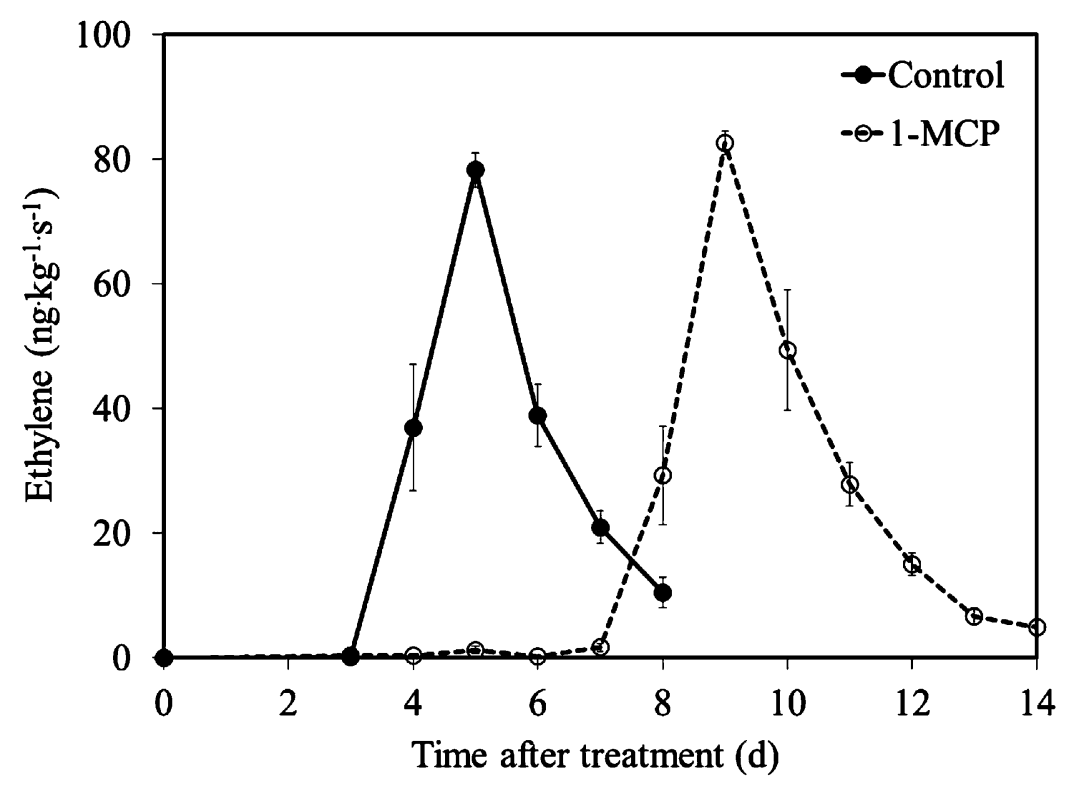

(A)

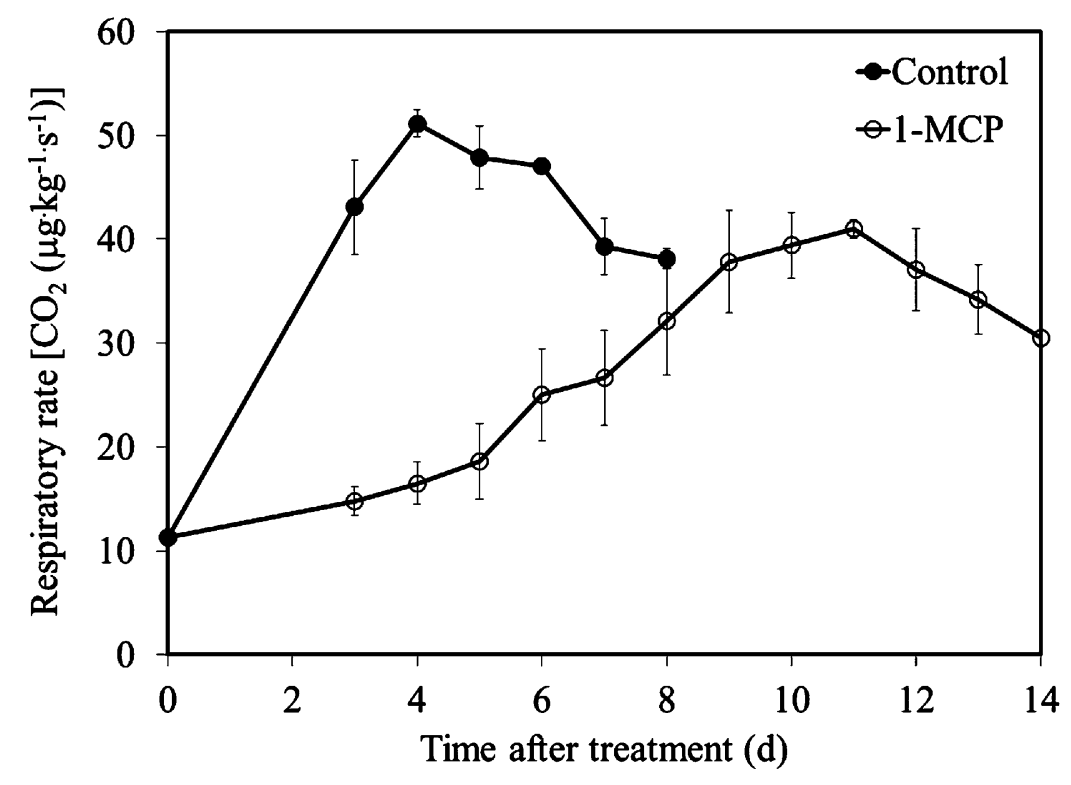

(B)

Fig. 2. Ethylene evolution (A) and respiratory rates (B) [as carbon dioxide $\left(\mathrm{CO}_{2}\right)$ evolution] of untreated 'Beta' avocados (control) or following immersion at preclimacteric stage in aqueous 1 -methylcyclopropene (1-MCP) solution at 2.77 $\mu \mathrm{mol} \cdot \mathrm{L}^{-1}\left[150 \mu \mathrm{g} \cdot \mathrm{L}^{-1}(\mathrm{ppb})\right]$ for $1 \mathrm{~min}$ and storage at $20^{\circ} \mathrm{C}\left(68.0{ }^{\circ} \mathrm{F}\right)$. Vertical bars represent \pm SE $(n=5) ; 1 \mu \mathrm{g} \cdot \mathrm{kg}^{-1}=1 \mathrm{ppb}, 1 \mathrm{ng} \cdot \mathrm{kg}^{-1}=0.001 \mathrm{ppb}$.

Table 1. Weight loss and peel color of ripe 'Beta' avocados untreated (control) or following immersion at preclimacteric stage in aqueous 1-methylcyclopropene (1-MCP) solution $2.77 \mu \mathrm{mol} \cdot \mathrm{L}^{-1}\left[150 \mu \mathrm{g} \cdot \mathrm{L}^{-1}(\mathrm{ppb})\right]$ for $1 \mathrm{~min}$ and storage at $20{ }^{\circ} \mathrm{C}\left(68.0{ }^{\circ} \mathrm{F}\right)$.

\begin{tabular}{lcccc}
\hline & & \multicolumn{3}{c}{ Peel color } \\
\cline { 3 - 5 } Treatment & Wt loss $(\%)$ & Lightness $\left(\mathrm{L}^{*}\right)$ & Chromaticity $\left(\mathbf{C}^{*}\right)$ & Hue angle \\
\hline Control & $4.3 \mathrm{~b}^{\mathrm{z}}$ & $52.6 \mathrm{a}$ & $45.9 \mathrm{a}$ & $115.1 \mathrm{~b}$ \\
l-MCP & $5.8 \mathrm{a}$ & $47.1 \mathrm{~b}$ & $39.0 \mathrm{~b}$ & $118.2 \mathrm{a}$ \\
\hline
\end{tabular}

${ }^{\mathrm{z}}$ Means followed by the same small letter in a column are not significantly different according to Duncan's multiple range test $(P \leq 0.05)$.
Fruit appearance can be negatively affected by $\mathrm{l}$-MCP treatment; shriveling was reported by Hurr et al. (2005) due to excessive weight loss in tomato during extended ripening, as there was atypical color development in banana (Golding et al., 1998) and tomato (Hurr et al., 2005). Despite the significant higher weight loss observed for 1-MCP-treated 'Beta' avocado in this study, likely due to the extended storage time to reach ripeness, there was no appearance of shriveling. However, the darker and greener peel color observed in treated fruit may negatively influence the consumer's purchase decision if based solely on peel color. 'Beta' avocado, a green-skinned Guatemalan-West Indian hybrid (Crane et al., 2007), remains light green or yellowish when ripe in contrast to the smaller MexicanGuatemalan hybrid 'Hass' which changes from a dark green to dark purple during ripening (Ashton et al., 2006).

The analysis of ripe pulp hardness gave evidence to the occurrence of a natural ripening asynchrony in untreated control 'Beta' fruit, with softer pulp toward the distal end of the fruit. Treatment with 1-MCP exacerbated ripening asynchrony, increasing the difference in pulp hardness among sections, even though aqueous 1-MCP was uniformly applied over the entire fruit surface during the 1-min immersion. Ripening asynchrony was reported by Choi et al. (2008) in avocado and tomato fruit partially immersed in aqueous 1MCP solution, without evidence of being influenced by the stem-end scar. This was unlikely due to the difference in whole fruit firmness, because actual average values for ripe fruit (11.5 N for control, 13.4 $\mathrm{N}$ for 1-MCP-treated) were not significantly different. The reason for the exacerbated difference observed for 'Beta' avocado in this study may be because of the embryonic growth, which occurs at the blossom end, accelerates ethylene sensitivity and production (Hershkovitz et al., 2009, 2010).

Despite the differences in pulp hardness, sensory analysis of 'Beta' avocado revealed that panelists could not distinguish between 1-MCPtreated fruit and untreated fruit. No significant effects of 1-MCP on sensory attributes were reported for other fruits such as mango [Mangifera indica 
Table 2. Hardness of segments of ripe mesocarp tissue taken from stem end (apical end), equatorial and blossom end (distal end) cross-sections of untreated 'Beta' avocados (control) or following immersion at preclimacteric stage in aqueous 1-methylcyclopropene (1-MCP) solution $2.77 \mu \mathrm{mol} \cdot \mathrm{L}^{-1}\left[150 \mu \mathrm{g} \cdot \mathrm{L}^{-1}\right.$ $(\mathrm{ppb})]$ for $1 \mathrm{~min}$ and storage at $20^{\circ} \mathrm{C}\left(68.0^{\circ} \mathrm{F}\right)$.

\begin{tabular}{llll}
\hline & & \multicolumn{2}{c}{ Treatment } \\
\cline { 3 - 4 } Hardness $(\mathbf{N})^{\mathbf{z}}$ & Location of cross-section & Control & 1-MCP \\
\hline First cycle & Stem end & $1.96 \mathrm{Ba}^{\mathrm{y}}$ & $6.19 \mathrm{Aa}$ \\
& Equatorial & $1.54 \mathrm{Bb}$ & $3.73 \mathrm{Ab}$ \\
Second cycle & Blossom end & $1.53 \mathrm{Bb}$ & $2.24 \mathrm{Ac}$ \\
& Stem end & $0.10 \mathrm{Aa}$ & $0.03 \mathrm{Aa}$ \\
& Equatorial & $0.09 \mathrm{Aa}$ & $0.03 \mathrm{Aa}$ \\
& Blossom end & $0.08 \mathrm{Aa}$ & $0.00 \mathrm{Aa}$ \\
\hline
\end{tabular}

${ }^{2}$ Determined as peak resistance values of cylindrical mesocarp samples $(10 \mathrm{~mm}$ diameter $\times 10 \mathrm{~mm}$ length $)$ to two compression-decompression cycles. After establishing zero force contact between the probe of the equipment and the top surface of the cylindrical sample, the probe was driven (compression) with a crosshead speed of $3.3 \mathrm{~mm} \cdot \mathrm{s}^{-1}$ to $70 \%$ of original sample height (first cycle), which was repeated (second cycle) immediately after first decompression; $1 \mathrm{~N}=0.2248 \mathrm{lbf}, 1 \mathrm{~mm}=0.0394$ inch.

${ }^{\mathrm{y}}$ For each cycle, values followed by the same small letter in a column or by the same capital letter in a row do not differ significantly according to Duncan's multiple range test $(P \leq 0.05)$.

Table 3. Average texture, flavor, and overall liking scores from 75 untrained panelists for ripe, untreated 'Beta' avocados (control) or following immersion at preclimacteric stage in aqueous 1 -methylcyclopropene (1-MCP) solution $2.77 \mu \mathrm{mol} \cdot \mathrm{L}^{-1}\left[150 \mu \mathrm{g} \cdot \mathrm{L}^{-1}(\mathrm{ppb})\right]$ for $1 \mathrm{~min}$ and storage at $20^{\circ} \mathrm{C}\left(68.0{ }^{\circ} \mathrm{F}\right)$.

\begin{tabular}{lccc}
\hline & Texture & Flavor & Overall liking \\
\cline { 2 - 4 } & & {$[\text { mean } \pm \text { SE }(1-9 \text { scale })]^{\mathrm{z}}$} & \\
\hline Control & $4.66 \pm 0.27 \mathrm{a}^{\mathrm{y}}$ & $5.01 \pm 0.27 \mathrm{a}$ & $4.72 \pm 0.27 \mathrm{a}$ \\
l-MCP & $4.52 \pm 0.25 \mathrm{a}$ & $4.69 \pm 0.25 \mathrm{a}$ & $4.57 \pm 0.24 \mathrm{a}$ \\
\hline
\end{tabular}

${ }^{2}$ Hedonic scale where $1=$ dislike extremely, $5=$ neither like nor dislike and $9=$ like extremely.

'Values followed by the same small letter in a column do not differ significantly according to Duncan's multiple range test $(P \leq 0.05)$.

(Cocozza et al., 2004)], kiwifruit (Harker et al., 2008), and tomato (Baldwin et al., 2011). However, apple (Marin et al., 2009; Pre-Aymard et al., 2005) and pear [Pyrus communis (Moya-Leon et al., 2006)] treated with 1-MCP were distinguishable from untreated fruit due to a higher fruit firmness. These latter reports show the importance of conducting sensory analyses to evaluate the consumer's perception of 1-MCP treatment.

The results of this study are encouraging for the avocado industry. However, because this study was not repeated in space or time and will not be continued, there are limitations due to the preliminary nature of these data. Nevertheless, it is clear that this technology has the potential to be used as a postharvest treatment of avocado to permit shipment of these fruit to more distant markets than currently possible.

\section{Literature cited}

Adkins, M.F., P.J. Hofman, B.A. Stubbings, and A.J. Macnish. 2005. Manipulating avocado fruit ripening with 1-methylcyclopropene. Postharvest Biol. Technol. 35:33-42.

Ashton, O.B.O., M. Wong, T.K. McGhie, R. Vather, Y. Wang, C. Requejo-Jackman, P. Ramankutty, and A.B. Woolf. 2006. Pigments in avocado tissue and oil. J. Agr. Food Chem. 54:10151-10158.

Baldwin, E., A. Plotto, J. Narciso, and J. Bai. 2011. Effect of 1-methylcyclopropene on tomato flavour components, shelf life and decay as influenced by harvest maturity and storage temperature. J. Sci. Food Agr. 91:969-980.

Blankenship, S.M. and J.M. Dole. 2003. 1-Methylcyclopropene: A review. Postharvest Biol. Technol. 28:1-25.

Choi, S.T. and D.J. Huber. 2008. Influence of aqueous 1-methylcyclopropene concentration, immersion duration, and solution longevity on the postharvest ripening of breaker-turning tomato (Solanum lycopersicum L.) fruit. Postharvest Biol. Technol. 49:147-154.

Choi, S.T., P. Tsouvaltzis, C.I. Lim, and D.J. Huber. 2008. Suppression of ripening and induction of asynchronous ripening in tomato and avocado fruits subjected to complete or partial exposure to aqueous solutions of 1-methylcyclo- propene. Postharvest Biol. Technol. 48: 206-214.

Cocozza, F.M., M.E.C. Pereira, R.E. Alves, H.A.C. Filgueiras, D.S. Garrutti, and J.T. Jorge. 2004. Sensory and physical evaluation of cold stored 'Tommy Atkins' mangoes influenced by 1-MCP and modified atmosphere packaging. Acta Hort. 645:655-661.

Crane, J., E. Evans, and C. Balerdi. 2007. A review of the Florida avocado industry. Proc. VI World Avocado Congr., Viña Del Mar, Chile, l Apr. 2013. <http:// www.avocadosource.com/WAC6/en/ Extenso/5a-209.pdf>.

Ding, H., Y.-W. Chin, A.D. Kinghorn, and S.M. D'Ambrosio. 2007. Chemopreventive characteristics of avocado fruit. Semin. Cancer Biol. 17:386-394.

Eaks, I.L. 1978. Ripening, respiration and ethylene evolution of 'Hass' avocado fruits at $20^{\circ}$ to $40^{\circ} \mathrm{C}$. J. Amer. Soc. Hort. Sci. 103:576-578.

Feng, X., A. Apelbaum, E.C. Sisler, and R. Goren. 2000. Control of ethylene responses in avocado fruit with 1-methylcyclopropene. Postharvest Biol. Technol. 16:143-150.

Florida Avocado Administrative Committee. 2008. Avocado shipping schedule for the 2008-2009 crop year. 1 Apr. 2013. <http://www.ams.usda.gov/AMSvl.0/ getfile?dDocName=STELPRDC5069057>.

Food and Agriculture Organization of the United Nations. 2013. 1 Apr. 2013. <http://faostat3.fao.org/home/index. html>.

Golding, J.B., D. Shearer, S.G. Wyllie, and W.B. McGlasson. 1998. Application of 1-MCP and propylene to identify ethylenedependent ripening processes in mature banana fruit. Postharvest Biol. Technol. 14: 87-98.

Harker, F.R., R.L. Amos, A. White, M.B. Petley, and M. Wohlers. 2008. Flavor differences in heterogeneous food can be detected using repeated measures of consumer preferences. J. Sens. Stud. 23:5264.

Hershkovitz, V., H. Friedman, E.E. Goldschmidt, and E. Pesis. 2009. The role of the embryo and ethylene in avocado fruit mesocarp discoloration. J. Expt. Bot. 60:791-799.

Hershkovitz, V., H. Friedman, E.E. Goldschmidt, and E. Pesis. 2010. Ethylene regulation of avocado ripening differs between seeded and seedless fruit. Postharvest Biol. Technol. 56:138-146.

Huber, D.J. 2008. Suppression of ethylene responses through application of 1-methylcyclopropene: A powerful tool 
for elucidating ripening and senescence mechanisms in climacteric and nonclimacteric fruits and vegetables. HortScience 43:106-111.

Hurr, B.M., J.H. Lee, and D.J. Huber. 2005. Differential responses in color changes and softening of 'Florida 47' tomato fruit treated at green and advanced ripening stages with the ethylene antagonist 1-methylcyclopropene. HortTechnology 15:617-622.

Instituto Brasileiro de Geografia e Estatística. 2013. Produção Agrícola Municipal. 4 Apr. 2013. <http://www.sidra. ibge.gov.br/bda/tabela/listabl.asp? c= $1613 \& z=p \& o=18>$.

Jeong, J. and D.J. Huber. 2004. Suppression of avocado (Persea americana Mill.) fruit softening, and changes in cell wall matrix polysaccharides and enzyme activities: Differential responses to 1-MCP and delayed ethylene application. J. Amer. Soc. Hort. Sci. 129:752-759.

Jeong, J., D.J. Huber, and S.A. Sargent. 2002. Influence of 1-methylcyclopropene (1-MCP) on ripening and cell wall matrix polysaccharides of avocado (Persea americana) fruit. Postharvest Biol. Technol. 25:241-256.

Kluge, R.A., A.P. Jacomino, R.M. Ojeda, and A. Brackmann. 2002. Avocado ripening inhibition by 1-methylcyclopropene. Pesquisa Agropecu. Bras. 37:895-901.

Marin, A.B., A.E. Colonna, K. Kudo, E.M. Kupferman, and J.P. Mattheis. 2009. Measuring consumer response to 'Gala' apples treated with 1-methylcyclopropene (1-MCP). Postharvest Biol. Technol. 51:73-79.
Moya-León, M.A., M. Vergara, C. Bravo, M.E. Montes, and C. Moggia. 2006. 1-MCP treatment preserves aroma quality of 'Packham's Triumph' pears during long-term storage. Postharvest Biol. Technol. 42:185-197.

Mworia, E.G., T. Yoshikawa, N. Salikon, C. Oda, W.O. Asiche, N. Yokotani, D. Abe, K. Ushijima, R. Nakano, and Y. Kubo. 2011. Low-temperature-modulated fruit ripening is independent of ethylene in 'Sanuki Gold' kiwifruit. J. Expt. Bot. 63: 963-971.

Nishiyama, K., M. Guis, J.K. Rose, Y. Kubo, K.A. Bennett, L. Wangjin, K. Kato, K. Ushijima, R. Nakano, A. Inaba, M. Bouzayen, A. Latche, J.C. Pech, and A.B. Bennett. 2007. Ethylene regulation of fruit softening and cell wall disassembly in charentais melon. J. Expt. Bot. 58:1281-1290.

Pereira, M.E.C., D.M. Tieman, S.A. Sargent, H.J. Klee, and D.J. Huber. 2013. Volatile profiles of ripening West Indian and Guatemalan-West Indian avocado cultivars as affected by aqueous 1-methylcyclopropene. Postharvest Biol. Technol. 80:37-46.

Pinheiro, A.C.M., E.V.B. Vilas Boas, and H.M.A. Bolini. 2010. Prolongamento da vida pós-colheita de bananas-maçã submetidas ao 1-metilciclopropeno (1-MCP) qualidade sensorial e física. Ciência e Tecnologia de Alimentos 30:132-137.

Pre-Aymard, C., E. Fallik, A. Weksler, and S. Lurie. 2005. Sensory analysis and instrumental measurements of 'Anna' apples treated with 1-methylcyclopropene. Postharvest Biol. Technol. 36:135-142.

Tacken, E., H. Ireland, K. Gunaseelan, S. Karunairetnam, D. Wang, K. Schultz, J.
Bowen, R.G. Atkinson, J.W. Johnston, J. Putterill, R.P. Hellens, and R.J. Schaffer. 2010. The role of ethylene and cold temperature in the regulation of the apple POLYGALACTURONASE1 gene and fruit softening. Plant Physiol. 153:294305 .

U.S. Department of Agriculture. 2013. Noncitrus fruits and nuts 2012 preliminary summary. 4 Apr. 2013. <http:// usda01.library.cornell.edu/usda/current/ NoncFruiNu/NoncFruiNu-01-25-2013.pdfs.

Watkins, C.B. 2006. The use of 1 methylcyclopropene (1-MCP) on fruits and vegetables. Biotechnol. Adv. 24:389409.

Watkins, C.B. 2008. Overview of 1methylcyclopropene trials and uses for edible horticultural crops. HortScience 43:86-94.

Yagiz, Y., H.G. Kristinsson, M.O. Balaban, and M.R. Marshall. 2007. Effect of high pressure treatment on the quality of rainbow trout (Oncorbynchus mykiss) and mahi mahi (Coryphaena hippurus). Food Chem. Technol. 72:C509-C515.

Zauberman, G., Y. Fuchs, U. Yanko, and M. Akerman. 1988. Response of mature avocado fruit to postharvest ethylene treatment applied immediately after harvest. HortScience 23:588-589.

Zhang, Z., D.J. Huber, and J. Rao. 2011. Ripening delay of mid-climacteric avocado fruit in response to elevated doses of 1-methylcyclopropene and hypoxiamediated reduction in internal ethylene concentration. Postharvest Biol. Technol. 60:83-91. 